\title{
Thank you, Professor Robert Schmidt
}

This special issue marks the end of Professor Robert Schmidt's longstanding editorship of Experimental Brain Research. Professor Schmidt has served as Editor for the journal since 1994.

We at Springer and the whole editorial team are very grateful to Professor Schmidt for his outstanding commitment and efforts on behalf of the journal.

It has been a pleasure and honor for us to be able to work with him over such a long and productive period of time.

We are pleased to announce that Professor John Rothwell, who has been co-editing the journal as Managing
Editor since 2006, is now taking over full responsibility for Experimental Brain Research.

We wish Professor Schmidt all the best for the future and are glad that he will stay connected with Springer through various book projects, including the recently published Encyclopedia of Pain (co-edited by Robert Schmidt and William Willis).

On behalf of the whole Springer team Andrea Pillmann

Senior Editor

Springer 